\title{
Microclimate Modification with Plastic Mulch
}

\author{
Julie M. Tarara ${ }^{1}$ \\ U.S. Department of Agriculture-Agricultural Research Service, Horticultural Crops Research Unit, \\ 24106 North Bunn Road, Prosser, WA 99350
}

\begin{abstract}
Horticultural production must achieve the maximum quality of a harvested organ in addition to sufficient yield. By contrast, the goal of agronomic production generally is to maximize the amount of plant biomass per unit of land area by maximizing the amount of solar radiation absorbed by the entire crop. Therefore, agronomic crops typically are planted at high densities so that the plants will cover the soil surface as rapidly as possible. In contrast, many horticultural systems are designed to optimize yield per plant rather than per unit land area; they demand less dense plant spacings to achieve the desired quality and to facilitate cultivation, harvesting, and produce handling. Less dense plantings create "sparse" crops, where the canopy does not fully shade the underlying surface. Therefore, environmental interactions in most horticultural crops include those between the plant and the exposed soil as well as those between the plant and the atmosphere.
\end{abstract}

The economic value of most horticultural crops routinely justifies modifying the crop's microclimate to accelerate growth, improve quality, and/or extend the growing season. Environmental modifications can be expensive, as in the cases of heated glasshouses and supplemental lighting, or they can be technologically simple and inexpensive, as in the case of home gardeners" "hot caps" or "wallo-water." To achieve the most economically efficient and biologically effective microclimate, one must understand the physics of energy transfer between the crop and the environment. Although these physical principles have not changed during the past 25 years (Tanner, 1974), we have improved some of the techniques of monitoring the crop microclimate and have measured energy exchanges in a variety of horticultural systems. This paper will review previous research and present new data to demonstrate the influence of black plastic mulch on the plant microclimate, with an analysis based on the physical principles outlined by Tanner (1974).

\section{PLASTIC MULCH}

Plastics chemistry is advanced enough to provide growers with a film with optical properties that are ideal for a specific crop in a given location (e.g., Graham et al., 1995; Splittstoesser and Brown, 1991; Stevens et al., 1991), but horticulturists first must define the optimum above- and below-ground environ-

Received for publication 27 May 1999. Accepted for publication 9 Sept. 1999. The cost of publishing this paper was defrayed in part by the payment of page charges. Under postal regulations, this paper therefore must be hereby marked advertisement solely to indicate this fact.

IFax:(509) 786-9277; e-mail:jtarara@ tricity.wsu.edu ments for that crop. For example, clear plastic mulch promoted the establishment of bermudagrass (Cynodon dactylon L.) during the fall, but the same mulch was detrimental to summer establishment because mean soil temperatures frequently exceeded those that are tolerated by these seedlings (Sowers and Welterlen, 1988). In a subtropical climate, peppers (Capsicum sp.) grew faster and set fruit earlier on white plastic mulch than on straw mulches (Vos and Sumarni, 1997), whereas in a hot, semiarid climate, black plastic resulted in scalding of the fruits and thus reduced yields (Roberts and Anderson, 1994). These reports and others show the importance of accounting for the above-ground as well as the below-ground influences of a mulch (Table 1). The list in Table 1 is far from exhaustive, but it illustrates the range of crops studied and the attention paid to particularly high-value crops like tomatoes (Lycopersicon esculentum Mill.) and peppers.

Black plastic is the overwhelming standard among growers worldwide (Schales, 1990), but specialized applications of other colored plastics have been documented. In hot climates, for example, season-long soil warming beneath a black plastic may be undesirable; white and aluminized reflective mulches are good alternatives. Typically, black and clear mulches raise soil temperatures above ambient, whereas white and aluminized plastics may either raise or lower soil temperature slightly. In early July in Kansas, daytime soil temperatures at $10 \mathrm{~cm}$ were $\approx 4{ }^{\circ} \mathrm{C}$ lower beneath white and aluminized reflective plastics than beneath black plastic, and 1 to $2^{\circ} \mathrm{C}$ lower than in bare soil (Ham et al., 1993). In a colorchanging system where black, photodegradable mulch is laid over white plastic, soil temperatures decline as the black mulch degrades and exposes more white plastic (Graham et al., 1995). This system warms soil rapidly in the spring and suppresses weeds during the entire season, while avoiding excessively high soil temperatures during the summer. Early yields of tomatoes were higher over red and black mulches, which induce higher soil temperatures, than over white and reflective plastics (Decoteau et al., 1989). The high early yields in tomatoes that have been regularly documented for black and clear plastic mulches (e.g., Bhella, 1988; Wien and Minotti, 1987, 1988; Wien et al., 1993) recently were attributed to preferential partitioning of carbon to fruits rather than to foliage (Teasdale and Abdul-Baki, 1997).

An above-ground spectral response exists in addition to the response to elevated soil temperatures, and may be physio-chemical (e.g., phytochrome regulation) or radiative (e.g., increasing or decreasing the heat load on the foliage). For example, in a pepper canopy, twice as much reflected photosynthetically active radiation $(P A R)$ was measured above clear plastic mulch than above black plastic or bare soil (Cebula, 1995). Elsewhere, white plastic reflected six times more $P A R$ than black and $\approx 50 \%$ more than a silver reflective mulch (Decoteau et al., 1989). Radiative effects were observed over a reflective, aluminum foil mulch that raised daily maximum air temperatures within a satsuma mandarin (Citrus unshui Kovich) canopy by up to $3^{\circ} \mathrm{C}$ and lowered minimum nighttime temperatures by 0.3 to $1.3^{\circ} \mathrm{C}$ (Richardson et al., 1993). Although both red and black plastics raised soil temperatures by the same amount, higher early yields and less foliage were observed in plants grown on the red plastic. Both red and black mulches reflected about the same amount of $P A R$, but red plastic increased the ratio of red to far-red (R:FR) in the reflected light (Decoteau et al., 1988, 1989). The R:FR ratio and the amount of blue light reflected toward the canopy apparently are critical. In turnips (Brassica rapa L.), blue and green mulches induced longer leaves and higher shoot : root ratios than white mulch. The R:FR ratio of light reflected from white plastic is lower than that of sunlight, which in turn is lower than that of blue or green plastics. Blue and green plastics differ in reflected blue light, which influenced the development of flavor compounds in the turnip roots (Antonius et al., 1996). Different R:FR ratios of light reflected from white, black, and red plastics altered the proportions of esters and alcohols in the foliar wax of pepper leaves (Kasperbauer and Wilkinson, 1995). In the same crop, the larger quantity of blue light reflected from white plastic resulted in a thicker cuticle.

One shortcoming of the literature on mulch is that most papers describe empirical studies of the response of some crop to mulching (Table 1), but few include extensive measurements of relevant microclimate variables. This is disconcerting because, as mentioned by Tanner (1974), the plant's transpiration rate and, in turn, its temperature, are tightly coupled with its microclimate. Micrometeorological data can contribute to the identification of the physiological mechanisms that drive a crop's response to mulching. However, measurements of only a few hours or days are inadequate for interpreting physiological responses, which can reflect changes in the microclimate from weeks or even months earlier (Monteith and Elston, 1971). More detailed environmental measurements must be incorporated into field studies if we are to separate complex physiological processes into individual components that respond to discreet variables in the physical environment.

The remainder of this paper will focus on plastic mulch and its effects on the transfer of 
Table 1 Summary: effects of plastic mulch on various crops

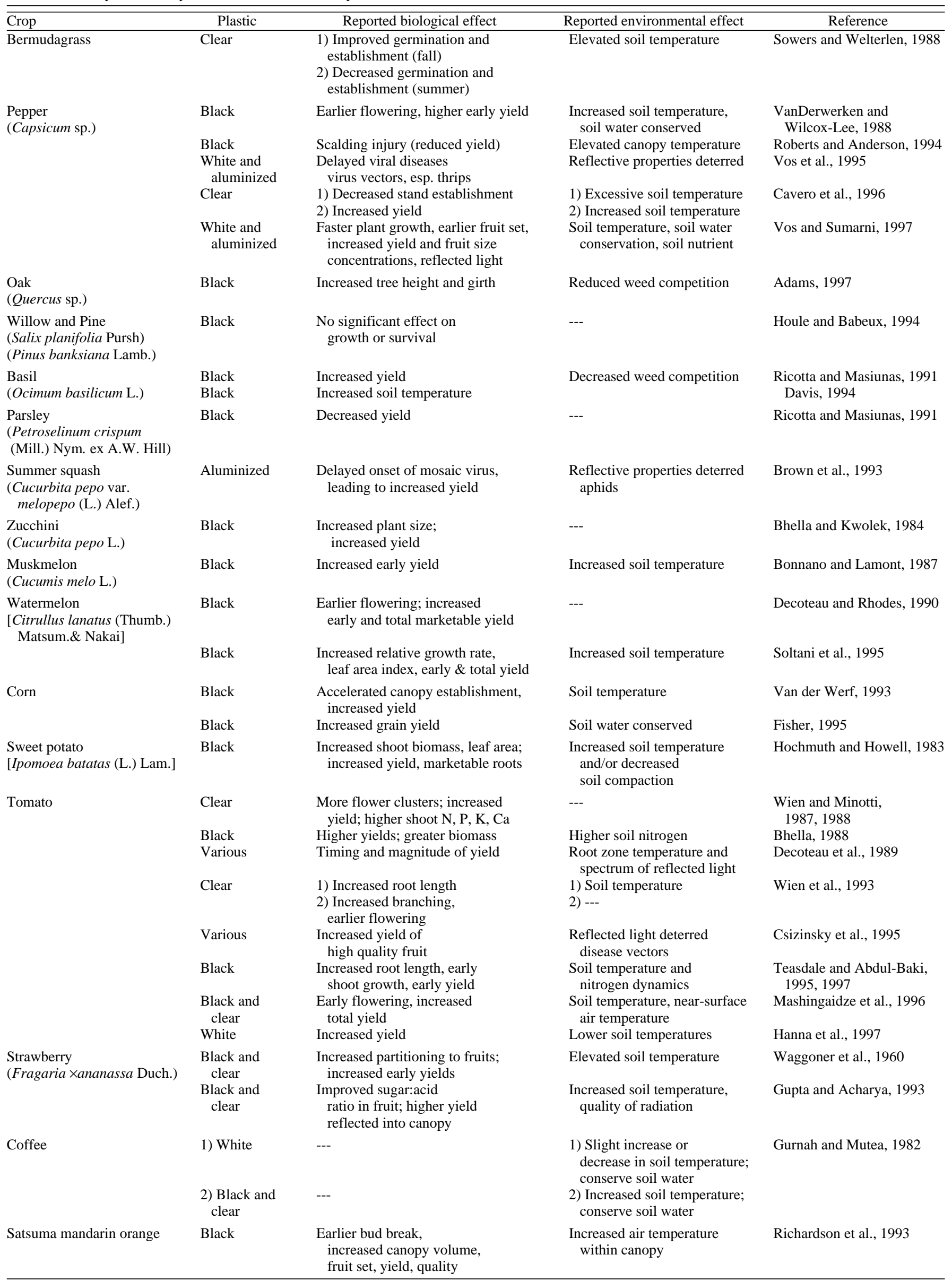


energy (i.e., heat) within the crop microclimate. An energy transfer accounting system, the "surface energy balance," will be reviewed, and data representing the energy balance of a mulched field will be presented. Each form of energy transfer in crops will be explained and typical measurement techniques mentioned. The subscripts "soil," "mulch," and "canopy" will denote energy transfer to or from the bare soil between strips of plastic mulch, to or from the plastic mulch, and to or from the crop, respectively.

\section{ENERGY (HEAT) EXCHANGE IN THE CROP ENVIRONMENT}

\section{Net radiation}

Net radiation $\left(\mathrm{R}_{\mathrm{n}}\right.$; Fig. 1$)$, the largest daytime energy input, is the sum of all radiation (R) exchange at the surface of a plant $\left(\mathrm{R}_{\mathrm{n} \text {,canopy }}\right)$, soil $\left(R_{n, \text { soil }}\right)$, or mulch $\left(R_{n, \text { mulch }}\right.$; Fig. 2$)$. It is composed of solar shortwave [(sw), 0.2 to $1.4 \mu \mathrm{m}]$ and terrestrial longwave $\left[\left(_{\mathrm{LW}}\right), 2\right.$ to $50 \mu \mathrm{m}]$ radiation. The peak wavelength for energy emitted by most terrestrial objects is $\approx 9 \mu \mathrm{m}$. Photosynthetically active radiation comprises the $0.4-0.7 \mu \mathrm{m}$ waveband; solar energy above $0.7 \mu \mathrm{m}$ is referred to as "nearinfrared" radiation. Longwave radiation often is called infrared or "thermal" radiation. Solar radiation may be a direct beam or may be diffuse due to scattering by clouds, atmospheric molecules, vegetation, a translucent rowcover, etc.; the total of direct and diffuse solar radiation is called global irradiance $\left(R_{S}\right)$. By convention, energy fluxes are assigned positive or negative values to denote their direction: energy transferred toward the crop (or soil, or mulch) is assigned a positive value, and energy moving away from the crop a negative value to define the direction of the vector [the energy flux (Fig. 2)]. Thus, daytime $R_{n}$, which is dominated by incoming $R_{s}$, is positive, but nighttime $R_{n}$, which is dominated by $R_{L W}$ leaving the crop or mulch surface, is negative.

Both solar and terrestrial radiation are absorbed, reflected, and transmitted in various proportions according to the optical properties of a surface: absorptance $(\alpha)$, reflectance $(\rho)$, and transmittance $(\tau)$. Table 2 lists optical properties of several surfaces, including black plastic mulch and various crops. Optical properties generally are listed as an average value for a particular waveband (e.g., $\alpha_{\text {sw }}$ for 0.2 $1.2 \mu \mathrm{m}$ ), weighted by the energy spectrum in the waveband. Soil, mulch, and other vegetation can reflect solar radiation toward a canopy, thereby increasing the total impinging on the plant surface (Fig. 2). For example, a reflective foil sheet covering the ground beneath an apple (Malus $\times$ domestica Borkh.) tree increased the absorption of $P A R$ by the canopy by $40 \%$ compared with bare soil and by $24 \%$ when the mulch covered half of the soil surface (Green et al., 1995).

All objects emit longwave radiation $\left(\mathrm{R}_{\mathrm{LW}}\right)$ as a function of their temperature and emissivity $(\varepsilon)$. Emissivity is the fraction of radiation emitted by a surface compared with that emit-

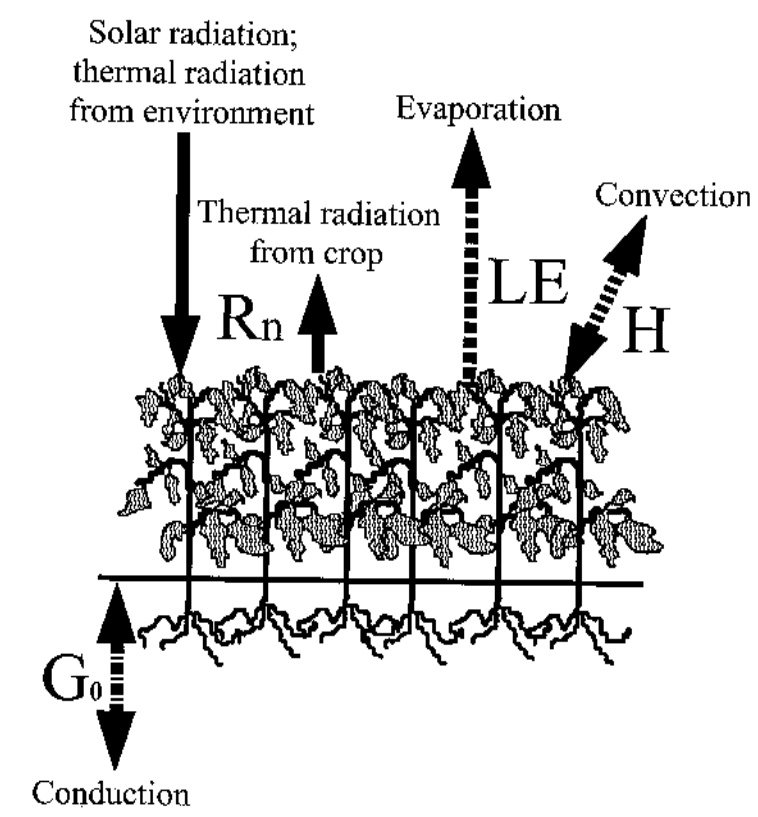

Fig. 1. Simplified schematic diagram of a surface energy balance for a crop with a uniform, closed canopy. Arrows denote direction of energy transfer. $\mathrm{R}_{\mathrm{n}}=$ net radiation; $\mathrm{G}_{0}=$ soil surface heat flux (conduction); $\mathrm{H}=$ sensible heat flux (convection); and $\mathrm{LE} \mathrm{=} \mathrm{latent} \mathrm{heat} \mathrm{flux} \mathrm{(evaporation).}$

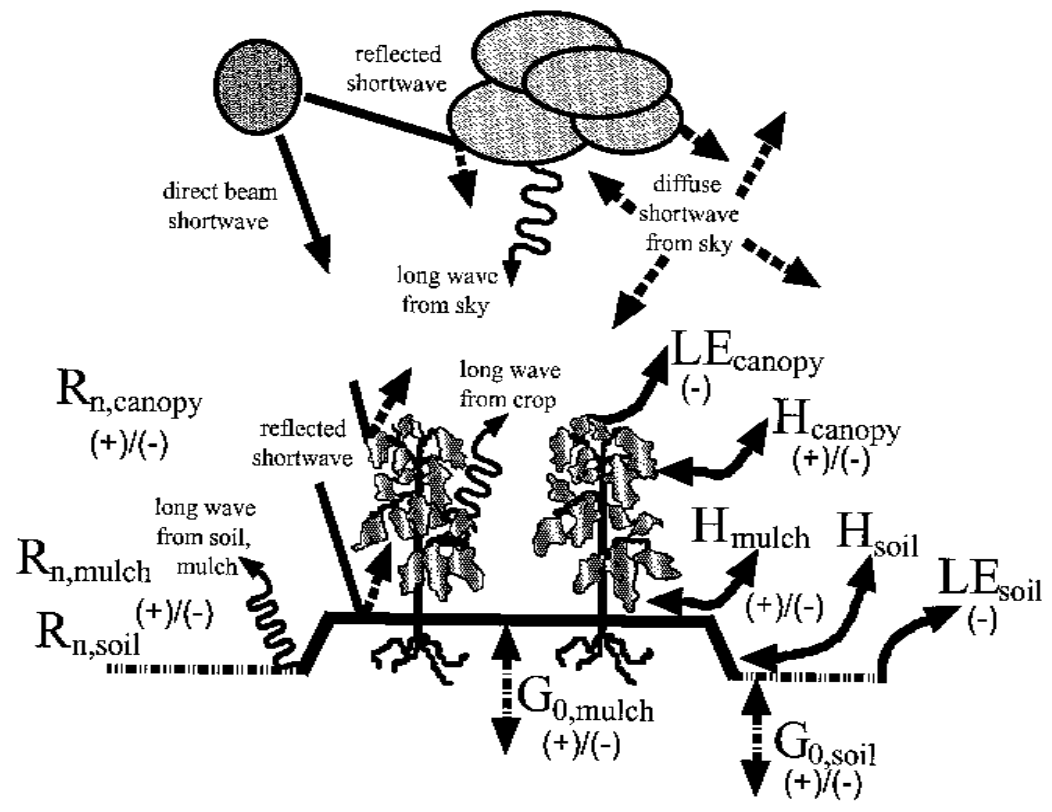

Fig. 2. Schematic diagram showing the components of the surface energy balances of plastic mulch, the bare soil between mulched rows, and the sparse crop atop the mulch. Energy fluxes are as in Fig. 1. The (+) denotes energy transport toward the surface and (-) denotes energy transport away from the surface.

ted by a "perfect" emitting body $(\varepsilon=1.0)$ at the same temperature, an ideal that does not exist in nature. The relationship is formalized by the Stefan-Boltzmann law:

$$
R_{L W}=\varepsilon_{s} \sigma T_{s}^{4}
$$

where $\sigma$ is the Stefan-Boltzmann constant $\left(5.67 \times 10^{-8} \mathrm{~W} \cdot \mathrm{m}^{-2} \cdot \mathrm{K}^{-4}\right)$ and $\mathrm{T}_{\mathrm{s}}$ is the temperature of the surface $(\mathrm{K})$. Using this formula we can calculate that a leaf at $20^{\circ} \mathrm{C}(\varepsilon=0.96)$ would emit $\approx 400 \mathrm{~W} \cdot \mathrm{m}^{-2}$ and black plastic mulch at $55^{\circ} \mathrm{C}(\varepsilon=0.92)$ would emit $\approx 600 \mathrm{~W} \cdot \mathrm{m}^{-2}$.

Over uniform surfaces, including closed canopies (Fig. 1), $R_{n}$ is measured with a net radiometer that accounts for both short- and longwave radiation. The instrument's output is the difference between downward and upward fluxes of both $\mathrm{R}_{\mathrm{SW}}$ and $\mathrm{R}_{\mathrm{LW}}$. Idso (1974) thoroughly reviewed the use and calibration of net radiometers, the basic design of which has not changed since that time. Measuring $R_{n}$ of distinct patches on a nonuniform surface, or of a sparse canopy, is technically more challenging because the radiometer, with a hemispherical view, may "see" more than the desired surface. For example, $R_{n}$ of an isolated tree was measured by use of eight net radiometers 
Table 2. Optical properties ${ }^{2}$ of various surfaces.

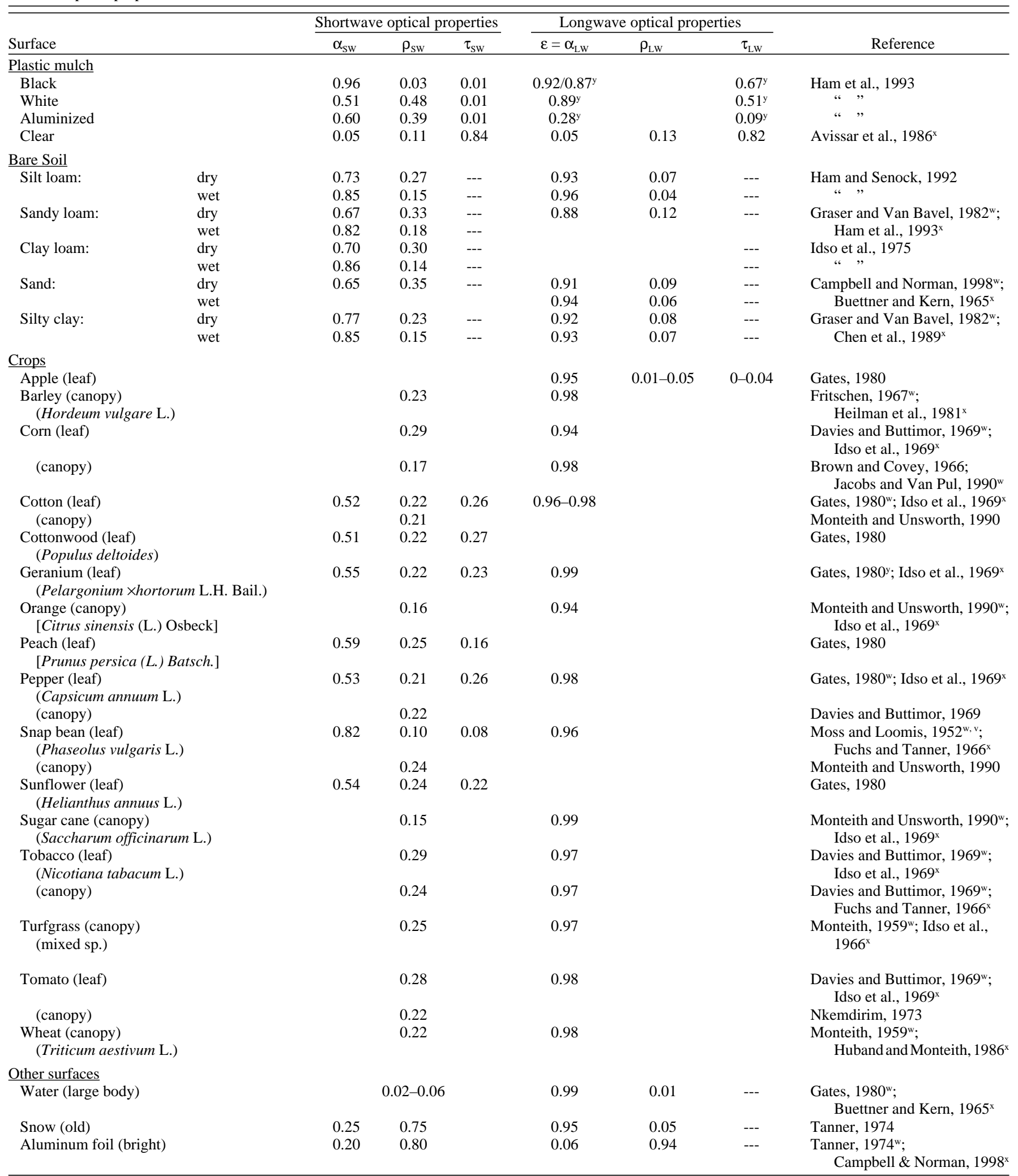

${ }^{\mathrm{z}} \alpha=$ absorptance; $\rho=$ reflectance $;=$ transmittance; $\varepsilon=$ emissivity; $_{\mathrm{sw}}=$ shortwave; $_{\mathrm{LW}}=$ longwave.

${ }^{y}$ Value for plastic on soil.

${ }^{\mathrm{x}}$ Longwave properties only.

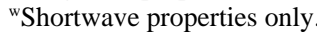

${ }^{\mathrm{v}}$ Mean of bean, tobacco, swiss chard, and spinach. 
mounted on a rotating, circular frame (Green, 1993; McNaughton et al., 1992). In addition to unique instrument configurations, mathematical adjustments must be made for the geometry of an irregular system and for the optical properties of any extraneous surfaces detected by the net radiometer. Such corrections become more complex with the patchiness of the surface and often require additional temperature measurements to calculate the longwave components of dissimilar surfaces. In the absence of direct measurements, $R_{n}$ can be calculated from equations that account for $R_{S}$, the optical properties of the surface, and the temperatures of the surface and its surroundings. Davies and Idso (1979) offer a comprehensive treatment on calculating the components of a surface radiation balance from standard meteorological data.

\section{Soil heat flux}

Heat transfer in soil (Fig. 1) occurs by conduction $(\mathrm{G})$ : the movement of energy by molecular vibrations in a solid or between a solid and motionless fluid. Heat moves upward to the surface (positive flux) or downward into the soil profile (negative flux) from warmer to cooler layers of soil according to Fourier's Law:

$$
G=-D_{H} \frac{\left(T_{2}-T_{1}\right)}{\left(z_{2}-z_{1}\right)}
$$

where $D_{H}$ is the thermal "diffusivity" of soilits ability to transmit heat $\left(\mathrm{W} \cdot \mathrm{m}^{-1} \cdot{ }^{\circ} \mathrm{C}^{-1}\right)$, and $\left(T_{2}-T_{1}\right) /\left(z_{2}-z_{1}\right)$ is the change in temperature (T) with depth in the soil (z). Conduction between an opaque plastic mulch and the underlying soil surface (Fig. 2) determines the effect of the mulch on soil temperature (Ham and Kluitenberg, 1994). Colored plastics (except aluminized, reflective mulches) absorb nearly all solar radiation, raising their surface temperature (Table 2). If the mulch has been installed tightly and is in direct contact with the soil, the thin layer of air between plastic and soil is minimized and heat is transferred readily by conduction, leading to a rise in soil temperature. Alternatively, if a plastic mulch is laid loosely, leaving an "air gap" between plastic and soil, then heat first must be conducted from the plastic to the still air layer before diffusing through the air gap and being transferred to the soil. Because air has a much lower thermal diffusivity than soil, heat transfer from the mulch in this scenario is slowed and most of the energy at the hot plastic surface is transferred by convection to the atmosphere.

To estimate heat flux at the soil surface $\left(\mathrm{G}_{0}\right)$, a "combination method" has been established as a standard technique (Kimball and Jackson, 1979). This method is a practical application of Fourier's Law that involves measuring conduction at some depth in the soil $\left(\mathrm{G}_{\mathrm{z}}\right)$, commonly 5 to $10 \mathrm{~cm}$, with heat flux plates (Fuchs, 1986), estimating the volumetric heat capacity $\left(\rho c_{p}\right)$ of the soil between the surface and the flux plates $(\Delta \mathrm{z}=5$ or $10 \mathrm{~cm})$, and measuring the rate of change in tempera- ture $\left(T_{2}-T_{1}\right) /\left(t_{2}-t_{1}\right)$ in that layer of soil:

$$
G_{0}=G_{z}+\rho c_{p} \frac{\left(T_{2}-T_{1}\right)}{\left(t_{2}-t_{1}\right)} \Delta z
$$

Historically, estimating $\rho c_{p}$ is the least reliable part of the combination method because it requires gravimetric sampling of the water content in the layer between the surface and the heat flux plates. Practical constraints limit the frequency of gravimetric sampling (e.g., daily to weekly). Recently, the development of a sensor to measure $\rho c_{p}$ directly, near the soil surface and in small volumes of soil (Campbell et al., 1991; Tarara and Ham, 1997) has improved the reliability of the combination method by providing frequent (e.g., hourly) measurements above the flux plate. Mayocchi and Bristow (1995) reviewed the measurement of $\mathrm{G}$ and discussed the impact of errors in measurement of $\rho c_{p}$ and potential errors connected with the depth of the evaporation front in the soil.

\section{Latent heat flux}

Evaporation affects energy transfer because of the latent heat of vaporization $(\lambda)$ : the amount of energy that is absorbed by water in changing from a liquid to a gas $\left(\lambda \approx 2450 \mathrm{~J} \cdot \mathrm{g}^{-1}\right)$. The same amount of energy is released when water condenses. Thus, condensation warms, but evaporation cools a surface. We use LE to denote "latent" (generally evaporative) heat flux. Evaporation transfers energy from the surface to the water vapor, which then diffuses or is carried into the atmosphere. Latent heat flux cools a leaf surface so that the temperature of a well-watered, transpiring canopy will be similar to, or lower than, that of the surrounding air. Canopy temperatures are related to transpiration rates. A parallel situation occurs at a wet soil surface: evaporation reduces the difference in temperature between the surface and the air.

In 1802, Dalton recognized a functional relationship among wind speed, atmospheric humidity, and temperature at the evaporating surface, although exact equations were not defined until much later (Brutsaert, 1982). For the past several decades, Ohm's Law (V = IR) has been applied to evaporation as a conceptual tool (Jones, 1992). Ohm's flow of current (I) is analogous to LE, Ohm's voltage potential (V) represents the difference in humidity between the evaporating surface and the air, and Ohm's electrical resistance $(\mathrm{R})$ becomes a conceptual analogue to the factors that limit LE. As with conduction, an equation states the relationship concisely:

$$
L E=-\lambda \frac{e_{s a t}\left(T_{s}\right)-e_{a}}{r_{a, v}+r_{s, v}}
$$

where $e_{\text {sat }}$ is the saturated vapor pressure at the temperature $\left(T_{s}\right)$ of the surface from which water evaporates and $e_{a}$ is the actual vapor pressure of the surrounding air. Thus, the difference in vapor pressure $\left[\mathrm{e}_{\mathrm{sat}}\left(\mathrm{T}_{\mathrm{s}}\right)-\mathrm{e}_{\mathrm{a}}\right]$ drives LE much like the difference in temperature drives conduction and, as will be shown, convection. The terms $r_{a, v}$ and $r_{s, v}$ represent aero- dynamic (i.e., fluid) and surface resistances to the transport of water vapor, respectively. They are related to wind speed and the properties of the evaporating surface (e.g., surface roughness). Often, one adds a stomatal resistance term when discussing transpiration from single leaves (Van den Honert, 1948) or a canopy resistance term $\left(\mathrm{r}_{\mathrm{c}, \mathrm{v}}\right)$ to describe LE from aggregate vegetation (Monteith, 1965). A review of the concept of $r_{c, v}$ was published recently by Lhomme (1991).

Although Eq. [4] helps to conceptualize evaporation, theoretical and logistical problems prevent us from using Eq. [4] to calculate actual LE in a mulched field. First, $r_{a, v}$ does not exist as a measurable, physical entity. Although $r_{\mathrm{s}, \mathrm{v}}$ can be defined from soil physical properties and $r_{c, v}$ from leaf area index and stomatal resistance, neither can be measured easily in sparse crops. Furthermore, $\mathrm{T}_{\mathrm{s}}$ is highly variable across patchy surfaces and in sparse vegetation, both spatially and temporally. However, the difficulty of predicting LE from patchy surfaces can be circumvented by measuring it directly. Direct measurement of xylem flow in a plant stem is one method of estimating sparse crop LE that avoids the limitations of Eq. [4]. The "sap flow gauge" (Baker and Van Bavel, 1987; Sakuratani, 1981, 1984) has been used to measure transpiration in cotton (Gossypium hirsutum L.) (Dugas, 1990; Ham et al., 1990), coniferous seedlings (Groot and King, 1992), prairie grasses (Bremer et al., 1996), corn (Zea mays L.) (Gavloski et al., 1992), and pecan [Carya illinoinensis (Wangenh.) K. Koch] trees (Steinberg et al., 1990), among many other species. Sap flow is converted to LE according to the leaf area of the plant and $\lambda$ (e.g., Ham et al., 1991):

$$
L E_{\text {canopy }}=-\lambda \frac{\sum_{i=1}^{n}\left(f_{i} / L_{i}\right)}{n \cdot L A I}
$$

where $\mathrm{f}$ is measured sap flow $\left(\mathrm{g} \cdot \mathrm{s}^{-1}\right)$ per plant and $\mathrm{L}$ is leaf area per plant $\left(\mathrm{m}^{2}\right)$.

Sap flows of transplanted tomatoes (Fig. 3) show the potential for differences in $\mathrm{LE}_{\text {canopy }}$ between mulched and bare soil plants, and the magnitude of transpiration in a sparse crop: maximum flows approached 250 to $300 \mathrm{~g} \cdot \mathrm{h}^{-1} \cdot \mathrm{m}^{-2}$ of leaf area $\left(-225 \mathrm{~W} \cdot \mathrm{m}^{-2} \mathrm{LE}_{\text {can }}\right.$ based on LAI). The plants shaded about half of the plastic (LAI = 1-2) and had already set fruit on the lowest trusses. Transplant density was $<1$ plant per $\mathrm{m}^{2}$ of land area. By contrast, irrigated corn in a high-density stand $(\approx$ 7.5 plants per $\mathrm{m}^{2}$ of land area) at the same location will transpire $\approx 100 \mathrm{~g} \cdot \mathrm{h}^{-1} \cdot \mathrm{m}^{-2}$ of leaf area when LAI is $\approx 5$ (closed canopy; J.M. Ham, unpublished data). Roughly speaking, 1 ha of sparse tomato plants may use the same amount of water as 1 ha of dense corn plants, but the corn distributes $\mathrm{LE}_{\text {canopy }}$ across more leaf area.

The horticultural goal of maximizing $R_{S}$ per plant also means increasing $R_{n}$ per plant, consequently inducing higher $\mathrm{LE}_{\text {canopy }}$ to dissipate that energy. Dense crops distribute the energy in $R_{S}$ and $R_{n}\left(W \cdot m^{-2}\right.$ of surface area) among a larger number of individual plants, thus reducing the total amount of energy that 


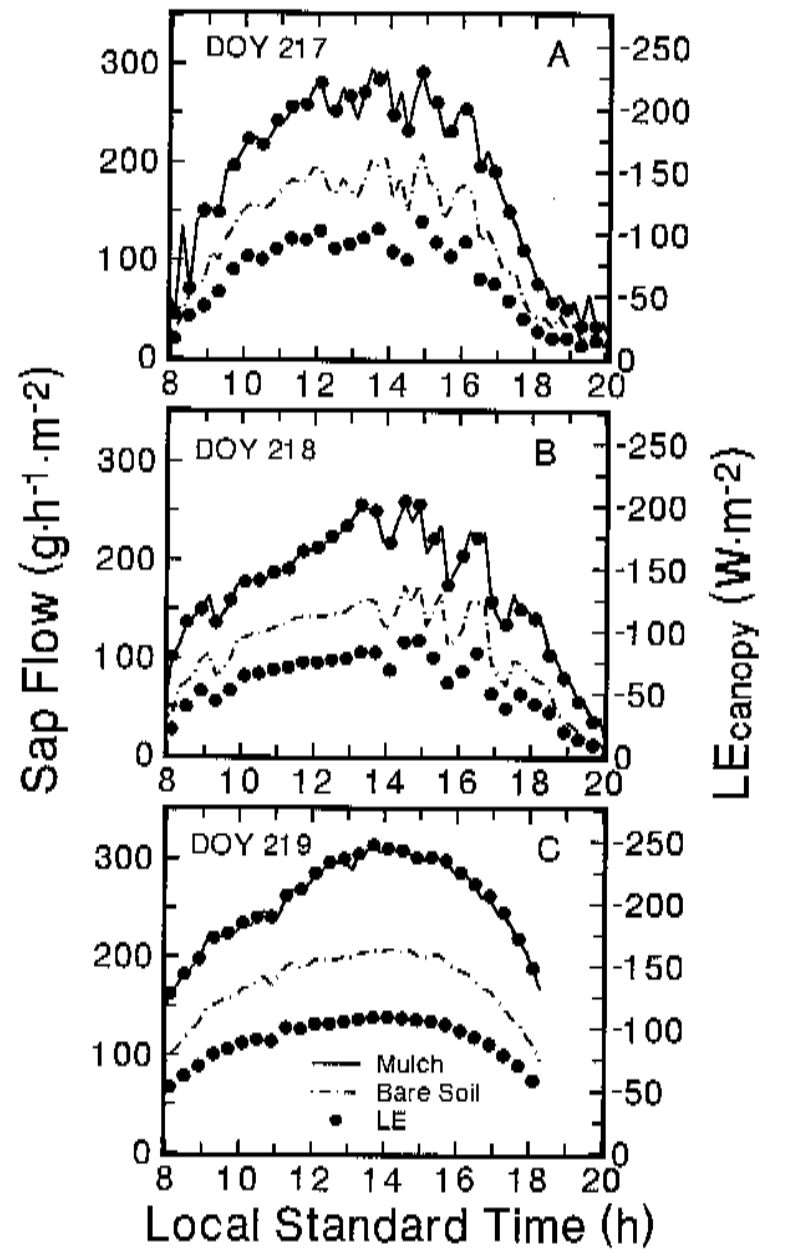

Fig. 3. Daytime sap flow and latent heat flux ( $\left.\mathrm{LE}_{\text {canopy }}\right)$ of tomato plants grown on black plastic mulch and bare soil, on Days of Year (A) 217, (B) 218, and (C) 219, 1995, near Manhattan, Kans. Sap flow is represented by the solid and dashed lines; $\mathrm{LE}_{\text {canopy }}$ is plotted by solid circles. The $\mathrm{LE}$ axis is scaled so that the data for the mulched plants fall along the sap flow line and bare soil values below the sap flow line. Data are mean values $(n=$ 5 ) and are normalized by leaf area. Mulched plants had on average $0.8 \mathrm{~m}^{2}$ of leaf area; plants on bare soil had somewhat more foliage $\left(1.2 \mathrm{~m}^{2}\right.$ per plant). Sap flow was measured by the heat-balance method. Mid-day coefficients of variation were $28 \%$ to $37 \%$ for mulched plants and $21 \%$ to $22 \%$ for bare soil plants.

a single plant must dissipate. Furthermore, dense canopies create a cool, humid microclimate because latent heat and water vapor are not rapidly transported away from the interior of the crop. Air movement inside a closed canopy is much less than that in an sparse crop (Arkin and Perrier, 1974; Perrier et al., 1970, 1972) even as late as harvest if the canopy never covers the surface of the field. This scenario is true of most upright crops grown on plastic mulch, as well as spaced plantings like orchards and vineyards. For example, in one vineyard, changes in trellising from narrow, compact hedgerows to a wider, less dense canopy resulted in higher $\mathrm{R}_{\mathrm{n}, \text { canopy }}$ and $\mathrm{LE}_{\text {canopy }}$, and lower $\mathrm{LE}_{\text {soil }}$ (Heilman et al., 1996). The size of coffee (Coffea arabica L.) trees grown in hedgerows markedly influenced energy transfer from the plantation. At low LAI, the relative distribution of LE between soil and canopy resembled that of a sparse row crop, but at high LAI, $\mathrm{LE}_{\text {canopy }}$ dominated and $\mathrm{LE}_{\text {soil }}$ was negligible, as one would expect above the closed canopy of a field crop (Gutiérrez and Meinzer, 1994).

Because plastic mulch is virtually impermeable to water and water vapor (Stevens et al., 1991; Waggoner et al., 1960), no evaporation occurs. Thus, there is essentially no $\mathrm{LE}_{\text {mulch }}$ (Fig. 2). Evaporation of dew or irrigation water from the surface of the plastic is a shortlived, intermittent process that has a trivial effect on the energy balance of the mulch surface over the course of a day. For the purposes of this discussion, such evaporation will be ignored. From bare soil, $\mathrm{LE}_{\text {soil }}$ occurs in relation to the water content of the surface and near-surface layers.

\section{Sensible heat flux}

Convection $(\mathrm{H})$ is the transfer of energy to or from a surface by a moving fluid; because it is heat that we can feel, $\mathrm{H}$ denotes "sensible" heat flux. In a crop system, the fluid is air (Fig. 1). Like conduction, convection is driven by a difference in temperature. In a mulch-sparse crop system (Fig. 2), convection is governed by mulch-air, soil-air, and canopy-air differences in temperature:

$$
H=-g_{h} \rho c_{p}\left(T_{s}-T_{a}\right)
$$

where $\mathrm{T}_{\mathrm{s}}$ is surface temperature; $\mathrm{T}_{\mathrm{a}}$ is air temperature; $\rho c_{p}$ is the heat capacity of air; and $\mathrm{g}_{\mathrm{h}}$ is a sensible heat "transfer coefficient"the constant of proportionality between the energy flux $(H)$ and its driving force $\left(\mathrm{T}_{\mathrm{s}}-\mathrm{T}_{\mathrm{a}}\right)$. Often, $\mathrm{g}_{\mathrm{h}}$ is conceptualized as a "conductance" to heat transfer that accounts for the aerodynamic characteristics of the surface and moving fluid. It varies with wind speed and the roughness of the surface, and mathematically is simply the inverse of the resistance concept introduced by Eq. [4]. In the literature, one is as likely to encounter equations of $\mathrm{H}$ in a "resistance" form as in a "conductance" form, the choice depending largely on the measurement techniques used and the conceptual preference of the author. 
Convection generally denotes the vertical transfer of energy; when $\mathrm{H}$ is transferred horizontally between patchy surfaces, it is called advection. Advection was identified in a number of early studies of sparse agronomic crops (e.g., Chin Choy and Kanemasu, 1974; Hanks et al., 1971). In a sparse cotton crop, advection from the dry soil surface (i.e., negative $\mathrm{H}_{\text {soil }}$ ) increased $L_{\text {canopy }}$ (Ham et al., 1990, 1991). In a vineyard in west Texas, advection from dry soil induced $17 \%$ to $36 \%$ of the evaporation from the vines (Heilman et al., 1994). These examples should be noted because the temperature differences between bare soil and a sparse canopy typically are less than those between a sparse canopy and many plastic mulches (Ham et al., 1993).

Sensible heat flux from plastic mulches and bare soil surfaces can be calculated from Eq. 6 if one records spatially representative measurements of $T_{s}, T_{a}$, and $g_{h}$. Estimates of $g_{h}$ can be obtained by applying the concept of a surface energy balance to "conductance sensors" (McInnes et al., 1994, 1996; Tarara and Ham, 1999). Similar techniques have been used to estimate $\mathrm{g}_{\mathrm{h}}$ for individual leaves (e.g., Brenner and Jarvis, 1995). Spatially representative measurements of soil surface and mulch temperatures are easier to obtain (Ham and Senock, 1992; Tarara and Ham, 1999) than are measurements of canopy temperature, especially in sparse crops where surface temperatures are highly variable. Infrared thermometry is well established for uniform vegetation (e.g., Fuchs and Tanner, 1966), but over seedlings the instrument will "see" both plant and underlying soil or mulch surface. It is possible to use infrared techniques in sparse canopies if corrections are made for the extent to which the canopy covers the soil and for the background radiation from the soil and/or sky that is detected by the instrument (Heilman et al., 1981; Lhomme et al., 1994; Stewart et al., 1994). These corrections are not trivial and are complicated further by the presence of a mulch.

\section{Surface energy balance}

The accounting system for energy transfer in a crop, the total "energy balance," can be expressed conveniently in an equation:

$$
R_{n}+G_{0}+H+L E+S+P=0
$$

where $\mathrm{S}$ is energy stored within the volume of the crop. The energy consumed by photosynthesis $(\mathrm{P})$, while critical to life, consumes $<1 \%$ of the energy in solar radiation and typically is ignored in energy balance calculations (Nobel, 1974). Energy turnover by metabolic processes likewise is neglected (Larcher, 1980). When a crop's canopy is "closed"-fully covering the underlying soil-Eq. 7 is simplified by treating the crop as a uniform, two-dimensional surface rather than a three-dimensional volume. This eliminates S, yielding the "surface energy balance" relation

$$
R_{n}+G_{0}+H+L E=0
$$

diagrammed in Fig. 1. Each term is expressed as a "flux density," or the rate of energy transfer per unit of surface area $\left(\mathrm{W} \cdot \mathrm{m}^{-2}\right)$. By

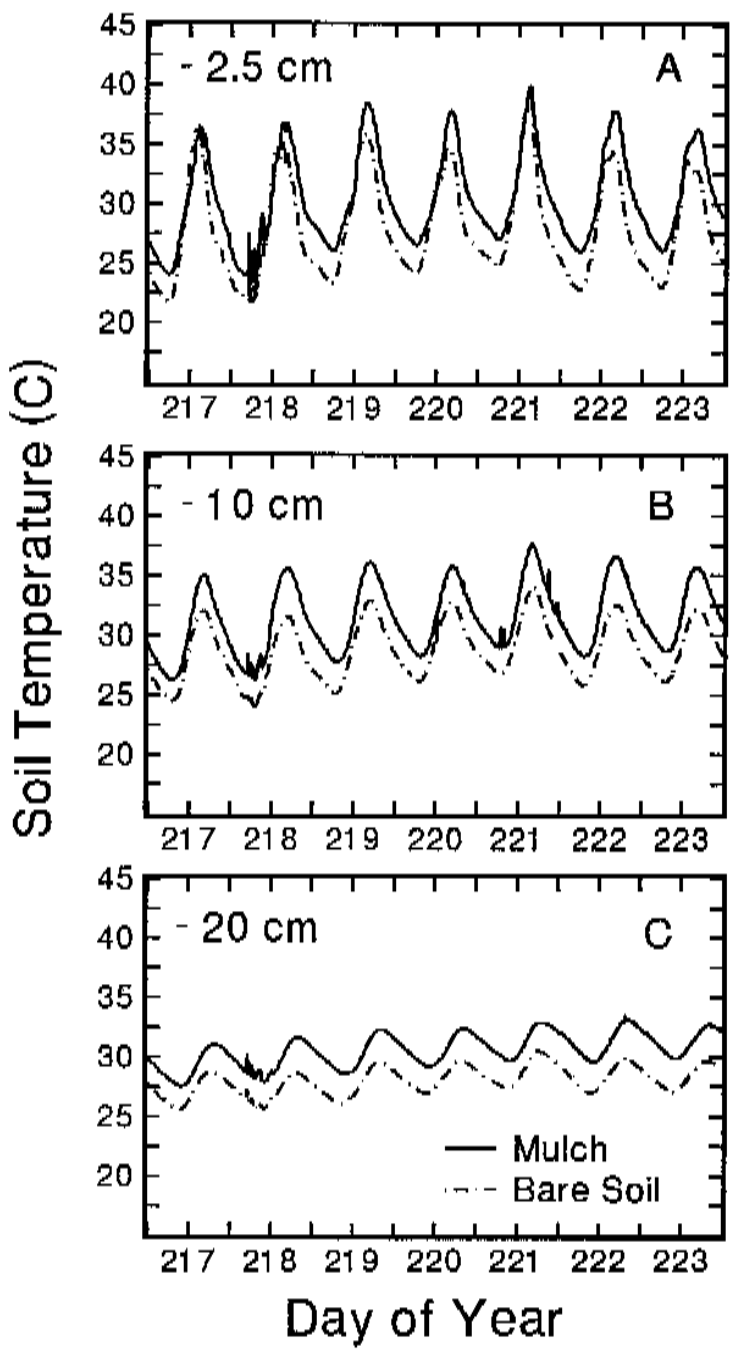

Fig. 5. Soil temperatures from Days of Year 217-223, 1995, at (A) $2.5 \mathrm{~cm},($ B) $10 \mathrm{~cm}$, and (C) $20 \mathrm{~cm}$ beneath a transplanted tomato crop on raised beds covered with black plastic mulch or left bare. The crop shaded at least half of the bed surface. Data were collected near Manhattan, Kans. Temperatures were measured along the center of the beds with thermocouples housed in hypodermic needles $(n=6$ per depth).

the law of Conservation of Energy, the surface energy balance must close; i.e., the sum of all energy transfer to and from the crop is zero. Equation 8 also is valid for determining the energy balance of a soil or mulch surface. Many researchers have found it attractive to measure or model $R_{n}, G$, and $H$, then solve a surface energy balance for LE (e.g., Brunel, 1989; Kustas, 1990).

In contrast, for a sparse crop on plastic mulch, we must determine three relationships:

$$
\begin{aligned}
& R_{n, \text { soil }}+G_{\text {soil }}+H_{\text {soil }}+L E_{\text {soil }}=0 \\
& R_{n, \text { mulch }}+G_{\text {mulch }}+H_{\text {mulch }}=0 \\
& R_{n, \text { canopy }}+H_{\text {canopy }}+L E_{\text {canopy }}=0
\end{aligned}
$$

A 24-h energy balance for black plastic mulch (Eq. 10) and for the bare soil between rows (Eq. 9) is shown in Fig. 4. When we separate the energy balances of a sparse crop, conduction at the soil surface $\left(\mathrm{G}_{0}\right)$ is not included in the energy exchange of the canopy (Eq. 11).

An energy balance cannot be measured directly. Rather, well-developed methods exist for measuring or estimating most of the variables in Eqs. 8-11. Solving these equations often is not the experimental goal per se, but instead is a means of estimating, rather than measuring directly, crop water use via $\mathrm{LE}_{\text {canopy }}$ (Tanner, 1960). Consequently, researchers have focused on either measuring $\mathrm{LE}_{\text {canopy }}$ itself or measuring $\mathrm{R}_{\mathrm{n}}, \mathrm{G}$, and $\mathrm{H}$ to solve Eq. 9 for $\mathrm{LE}_{\text {soil }}$ and Eq. 11 for $\mathrm{LE}_{\text {canopy }}$ to estimate crop water use. Historically, sparse crops have received less attention in research because their irregular aerodynamic and optical properties present significant technical and theoretical difficulties to measuring the components of the energy balance. Field-scale techniques that are appropriate for solving Eq. [8] over a closed canopy do not provide the detail necessary to separate the energy balance of sparse vegetation from that of the bare soil or a plastic mulch (Eqs. 9-11; Fig. 2).

\section{MICROCLIMATE MODIFICATION BY PLASTIC MULCH: APPLICATIONS}

The surface energy balance of plastic mulch and its influence on the above- and below- 
ground crop environment are determined by both the optical properties of the plastic (Ham et al., 1993; Waggoner et al., 1960) and the degree of contact between the plastic and the underlying soil (Ham and Kluitenberg, 1994; Liakatas et al., 1986). The link between mulchsoil contact and mulch optical properties is illustrated by seemingly conflicting reports on soil temperature. These observations merit attention because growers have been advised to use clear plastic to "solarize" soil and opaque plastics to control weeds. Higher soil temperatures have been recorded beneath black plastic mulch, which transmits only $1 \%$ of $R_{s}$, than beneath clear plastic, which transmits up to $84 \%$ of $\mathrm{R}_{\mathrm{S}}$ (Ham et al., 1993). Stretching the plastic film tightly across the soil apparently results in more effective soil heating by conduction than by direct transmission of solar radiation (Ham and Kluitenberg, 1994). Conversely, laying mulch loosely across the soil creates an insulating layer of air between plastic and soil, causing higher daytime soil temperatures under clear than under black plastic (Liakatas et al., 1986). In many reports where the extent of soil-plastic contact was not stated explicitly, clear plastic induced more extreme diurnal fluctuations in soil temperature than did black plastic (e.g., Bonanno and Lamont, 1987; Cebula, 1995; Waggoner et al., 1960). However, less extreme fluctuations were observed under clear than under black plastic when both were tightly stretched across raised beds (Ham et al., 1993). Generally, one can expect the highest midday soil temperatures under mulches with high shortwave absorptance (i.e., black) or high shortwave transmittance (i.e., clear).

During July in North Carolina, Wu et al. (1996) found that soil temperatures beneath clear plastic were 5 to $15^{\circ} \mathrm{C}$ higher at $10 \mathrm{~cm}$ and 4 to $12^{\circ} \mathrm{C}$ higher at $20 \mathrm{~cm}$ than beneath bare soil. Elevated temperatures were observed up to $30 \mathrm{~cm}$. In Kansas, under a tomato crop that shaded about half of a mulched bed, soil temperatures were consistently 3 to $5^{\circ} \mathrm{C}$ higher beneath black plastic than beneath bare soil, to depths of at least $20 \mathrm{~cm}$ (Fig. 5). Elevated soil temperatures were observed as late as harvest [Days of Year (DOY) 240-260], at which time the plants shaded most of the mulch. At the same site, in the absence of a crop, midday soil temperatures at $2.5 \mathrm{~cm}$ were up to $8{ }^{\circ} \mathrm{C}$ higher beneath black plastic mulch than under bare soil (Fig. 6B). These raised beds $(13 \mathrm{~cm}$ high, $72 \mathrm{~cm}$ wide) had good mulch-soil contact.

Black plastic mulch and bare soil can have similar $R_{n}$ (Fig. 7). At first glance, one might expect $R_{n, \text { mulch }}$ to exceed $R_{n, \text { soil }}$ because the black plastic absorbed $96 \%$ of $\mathrm{R}_{\mathrm{S}}$ while the bare soil absorbed only $67 \%$. However, the mulch surface was generally warmer than the bare soil surface (Fig. 6A), thereby emitting more longwave radiation $\left(\varepsilon_{\text {mulch }}=0.87\right.$; $\left.\varepsilon_{\text {soil }}=0.88\right)$. Net radiation differed by $\approx 70 \mathrm{~W} \cdot \mathrm{m}^{-2}$ near midday when the soil surface was dry (Fig. 7A). When the bare soil surface was wet (Fig. 7B) its shortwave absorptance $\left(\alpha_{\text {sw }}\right)$ increased (Table 2$)$, which we would expect because a wet soil is darker than a dry
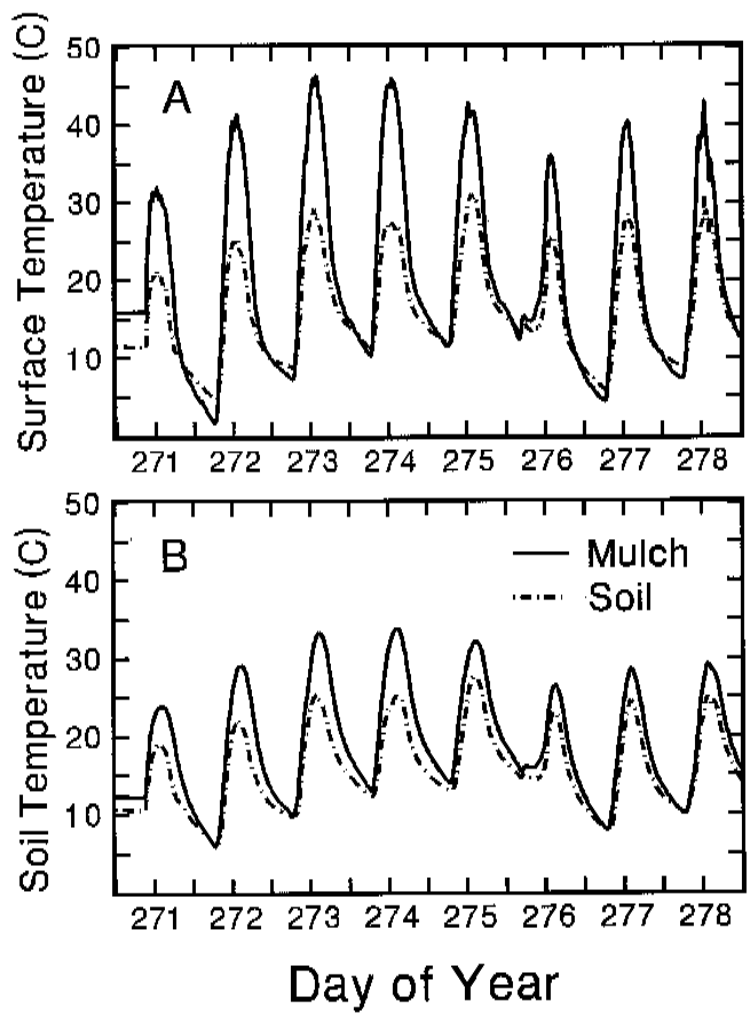

Fig. 6. (A) Surface temperature and (B) soil temperature at $2.5 \mathrm{~cm}$ for black plastic mulch and the bare soil between mulched beds, near Manhattan, Kans. Day lengths and solar declination were similar to those in early spring when mulches generally are installed in the field. Days of Year (DOY) 271-278, 1996, represent the period during which the surface of the bare soil gradually dried after $35 \mathrm{~mm}$ of rain on DOY 269-270. Mulch surface temperature was measured with fine-wire thermocouples glued to the underside of the plastic $(n=9)$. Soil surface temperature was measured with soil-encapsulated thermocouples $(n=9)$. Soil temperature $(n=3)$ was measured with thermocouples housed in hypodermic needles.

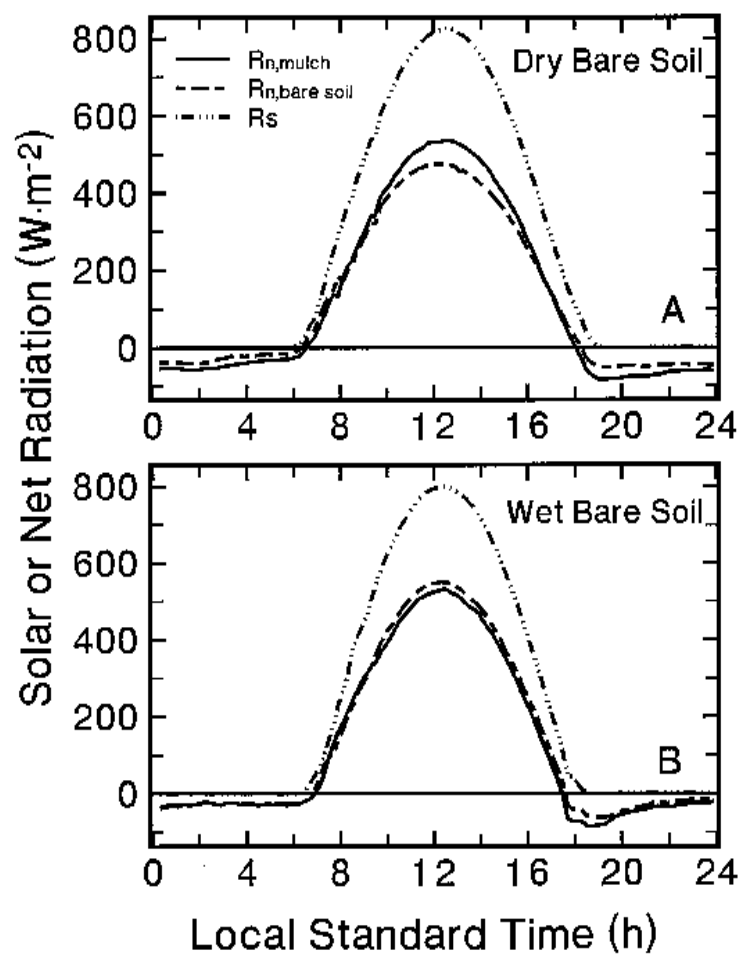

Fig. 7. Net radiation $\left(R_{n}\right)$ and total solar radiation $\left(R_{S}\right)$ for black plastic mulch and bare soil near Manhattan, Kans., on Day of Year 248 (dry, bare soil) and 272 (wet, bare soil), 1996. $R_{S}$ was measured by a pyranometer (Model 8-48; Eppley Laboratories, Newport, R.I.) mounted $2 \mathrm{~m}$ above the field. $\mathrm{R}_{\mathrm{n}}$ was measured as in Fig. 4. 
one. Also, evaporation $\left(\mathrm{LE}_{\mathrm{soil}}\right)$ cooled the surface. Higher $\alpha_{\mathrm{Sw}}$ (more $\mathrm{R}_{\mathrm{S}}$ absorbed) coupled with a lower surface temperature than under dry conditions (less outgoing $\mathrm{LW}$ ) resulted in $\mathrm{R}_{\mathrm{n}, \text { soil }} \approx \mathrm{R}_{\mathrm{n} \text {,mulch }}$ around midday. Both $\mathrm{R}_{\mathrm{n} \text {,soil }}$ and $R_{n, \text { mulch }}$ track the diurnal pattern of $R_{S}$. At night, $R_{n}$ typically is slightly negative; global irradiance is zero and the longwave radiation emitted by each warm surface (negative flux) exceeds that absorbed from the cooler surroundings (positive flux).

Because of its large $\alpha_{\mathrm{sw}}$ (Table 2), the surface temperature of black plastic mulch can be relatively high during the day (Fig. 6A), leading directly to a large amount of emitted $\mathrm{R}_{\mathrm{LW}}$ (e.g., $475 \mathrm{~W} \cdot \mathrm{m}^{-2}$ at $40{ }^{\circ} \mathrm{C}$ and $575 \mathrm{~W} \cdot \mathrm{m}^{-2}$ at $55^{\circ} \mathrm{C}$ ) that contributes to the incoming $\mathrm{R}_{\mathrm{LW}}$ of $\mathrm{R}_{\text {n,canopy }}$ (Fig. 2). If we assume that a white plastic surface is $\approx 15^{\circ} \mathrm{C}$ cooler than a black one (Ham et al., 1993), emitted longwave would be somewhat lower $\left(400 \mathrm{~W} \cdot \mathrm{m}^{-2}\right.$ at $25^{\circ} \mathrm{C}$ and $485 \mathrm{~W} \cdot \mathrm{m}^{-2}$ at $40{ }^{\circ} \mathrm{C}$ ) from the white mulch. Black mulch reflects only a small amount of $R_{S}$ into the canopy, $<25 \mathrm{~W} \cdot \mathrm{m}^{-2}$ around noon on a sunny day (e.g., $3 \%$ of $800 \mathrm{~W} \cdot \mathrm{m}^{-2}$ ). By contrast, white plastic reflects $48 \%$ of $\mathrm{R}_{\mathrm{S}}$ toward the canopy (e.g., $385 \mathrm{~W} \cdot \mathrm{m}^{-2}$ of an incident $800 \mathrm{~W} \cdot \mathrm{m}^{-2}$ ). Therefore, total radiation directed toward the canopy is higher above a white $\left(785-870 \mathrm{~W} \cdot \mathrm{m}^{-2}\right)$ than above a black plastic $\left(500-600 \mathrm{~W} \cdot \mathrm{m}^{-2}\right)$. Assuming equal $\mathrm{T}_{\mathrm{a}}$ above both mulches and a $15{ }^{\circ} \mathrm{C}$ difference in surface temperature, $\mathrm{H}_{\text {mulch }}$ would be higher from the black $\left(370-500 \mathrm{~W} \cdot \mathrm{m}^{-2}\right)$ than the white surface $\left(60-200 \mathrm{~W} \cdot \mathrm{m}^{-2} ; \mathrm{T}_{\mathrm{a}}=22\right.$ and $\left.30^{\circ} \mathrm{C}\right)$. Thus, in this scenario, although the sum of radiation leaving a white plastic is higher than that leaving a black plastic, the total energy directed at the canopy via radiation and convection would be quite similar $(\approx 850$ to $1100 \mathrm{~W} \cdot \mathrm{m}^{-2}$ ) for these two plastics with very different optical properties.

Plastic mulches influence the above-ground environment via radiation, transpiration, convection, and photobiology. Additionally, planting holes cut through plastic mulches potentially direct $\mathrm{CO}_{2}$ toward the canopy of seedlings, the so-called "chimney effect." As much as $2 \times$ ambient concentrations have been measured above holes cut for transplants (Soltani et al., 1995).

Convection is the major mechanism of energy transfer from plastic mulch and from dry, bare soil. A midday temperature profile from the surface to $2 \mathrm{~m}$ illustrates the driving force for $\mathrm{H}$ (Eq. [6]; Fig. 8). The black plastic was $\approx 20^{\circ} \mathrm{C}$ warmer than the air $2.5 \mathrm{~cm}$ above it; dry, bare soil between mulched beds was $\approx 7^{\circ} \mathrm{C}$ warmer than the overlying air. At one site, mean daily air temperatures above white and clear plastics were within $1{ }^{\circ} \mathrm{C}$ of those above bare soil while air temperatures above black plastic were $\approx 5^{\circ} \mathrm{C}$ higher (Wien et al., 1993). Therefore, black plastic mulch can obviously contribute a significant amount of sensible heat to the aerial environment of a sparse crop. Daytime $\mathrm{H}_{\text {mulch }}$ for black plastic ranged from $<10 \%$ to $>90 \%$ of $R_{n \text {,mulch }}$ over the course of a day, but did not change with the wetness of the soil surface between beds (Fig. 9A). Midday $\mathrm{H}_{\text {mulch }}$ was $\approx 60 \%$ of $\mathrm{R}_{\mathrm{n} \text {,mulch }}$, whereas

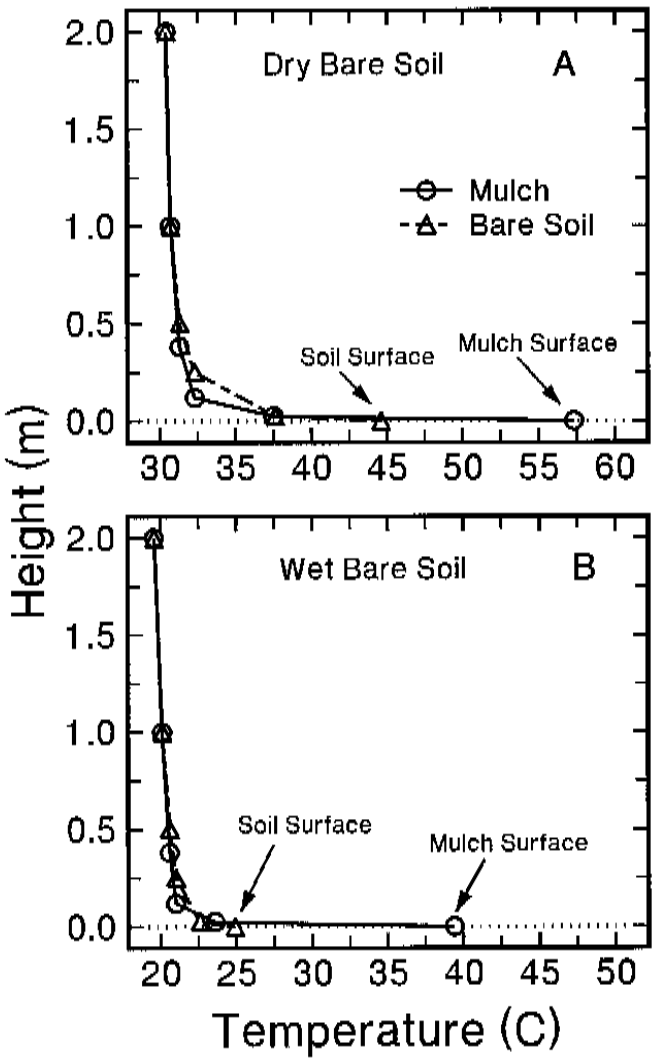

Fig. 8. Mid-day temperature profile from the surface of black plastic mulch and bare soil to $2 \mathrm{~m}$, on Day of Year (DOY) 248 and 272, 1996, near Manhattan, Kans. Wind speeds were similar on the two days (daily mean $=2.3 \mathrm{~m} \cdot \mathrm{s}^{-1}$ [DOY 242] and $1.9 \mathrm{~m} \cdot \mathrm{s}^{-1}$ [DOY 272]). Surface temperatures were measured as in Fig. 6; air temperatures were measured with shielded, aspirated, fine wire thermocouples.

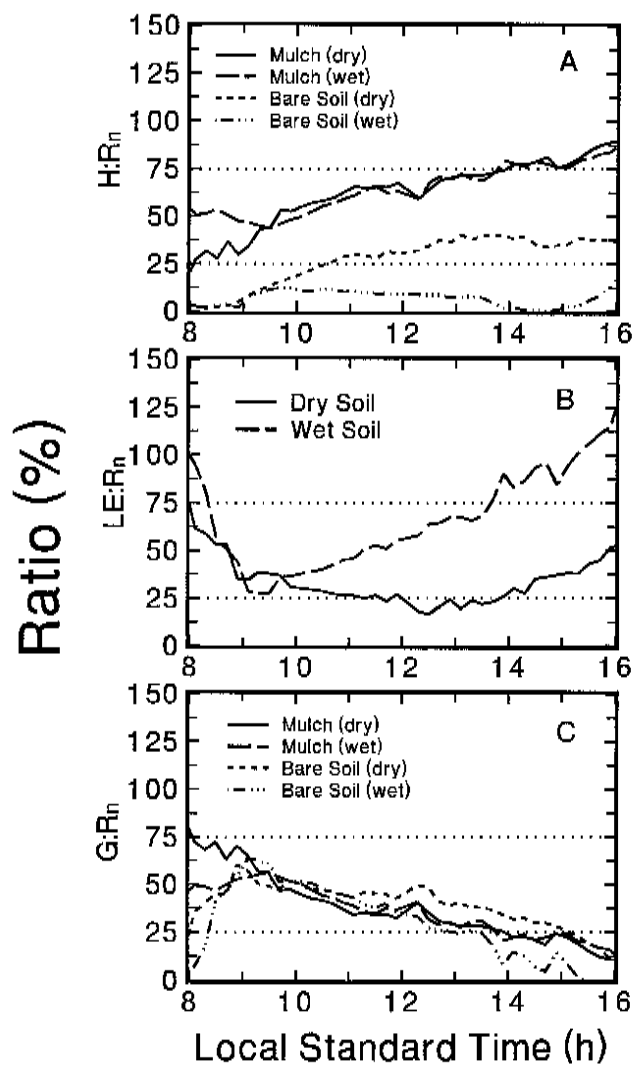

Fig. 9. (A) Sensible (H), (B) latent (LE), and (C) soil surface $\left(\mathrm{G}_{0}\right)$ heat flux as a percentage of net radiation $\left(\mathrm{R}_{\mathrm{n}}\right)$ for black plastic mulch and the bare soil surface between mulched beds. The data are for Day of Year (DOY) 248 (dry) and DOY 272 (wet), 1996, as in Fig. 7. Fluxes were measured with the methods described in Fig. 4. 
$\mathrm{H}_{\text {soil }}$ did not exceed $40 \%$ of $\mathrm{R}_{\mathrm{n} \text {,soil }}$ from a visibly dry soil surface or $10 \%$ of $R_{n, \text { soil }}$ from a visibly wet surface. Midday $L_{\text {soil }}$ dissipated $\approx 25 \%$ of $\mathrm{R}_{\mathrm{n}, \text { soil }}$ when the surface was dry and upwards of $60 \%$ of $\mathrm{R}_{\mathrm{n} \text {,soil }}$ when the surface was wet (Fig. 9B). From a wet surface, $\mathrm{H}_{\text {soil }}$ generally is small and may be either positive or negative depending on surface and air temperatures. If $\mathrm{T}_{\mathrm{a}}>\mathrm{T}_{\mathrm{s}}\left(\mathrm{i} . \mathrm{e} ., \mathrm{H}_{\text {soil }}, \mathrm{H}\right.$ positive) the soil surface absorbs energy from the air and if $\mathrm{T}_{\mathrm{s}}>\mathrm{T}_{\mathrm{a}}$ (i.e., $\mathrm{H}_{\text {soil }}$ negative) heat is transported from the soil surface to the overlying layer of air.

Any differences in $\mathrm{G}_{0}$ between mulch-covered and bare soil occurred during early morning and late afternoon (data not shown) when solar radiation, hence energy absorbed by the surface, was changing rapidly. Black plastic absorbed more solar radiation $\left(\alpha_{\text {mulch }}=0.96\right.$; $\alpha_{\text {soil }}=0.67$ ), thereby creating a larger difference in temperature between the plastic and underlying soil than between the bare surface and its adjacent soil layer. During the day, $\mathrm{G}_{0}$ dissipated between $25 \%$ and $50 \%$ of $\mathrm{R}_{\mathrm{n}}$ (Fig. 9C). Data collected in Kansas indicated that simulated $\mathrm{G}_{0}$ was comparable beneath clear and black plastic mulches (Ham and Kluitenberg, 1994). Neither plastic induced large fluxes, even during midsummer, because once energy was transferred from the plastic to the soil surface the extent of conduction depended on the thermal properties of the soil. A white-on-black plastic (white side up), which reflects $48 \%$ of $R_{s}$, caused the lowest simulated $\mathrm{G}_{0}$. In midsummer, surface temperatures were as much as $17^{\circ} \mathrm{C}$ lower on white than on black plastic mulches (Ham et al., 1993).

The geometry of a mulch-soil system also influences $\mathrm{G}_{0}$. Raised beds lead to a larger conducting surface that is isolated on two sides from the rest of the soil. Under a clear mulch, high soil temperatures $\left(>35^{\circ} \mathrm{C}\right)$ occurred more often in raised beds than in level soil (Cavero et al., 1996). An average temperature increase of 2 to $4{ }^{\circ} \mathrm{C}$ has been reported for raised beds (Chellami et al., 1997). The width of mulched strips can be manipulated to minimize a well documented "edge effect," where the increase in soil temperatures beneath a mulch declines from the center to the edge of the plastic (Mahrer and Katan, 1981). Beds $>60 \mathrm{~cm}$ wide apparently minimize the edge effect. However, in one solarization study, a gradient of decreasing soil temperature from the middle to the edge of a 2.5 -m-wide mulched strip was correlated with a corresponding gradient in nematode control and in plant height (Grinstein et al., 1995).

In sparse crops, management practices that are intended to reduce soil evaporation, including plastic mulch, may increase $\mathrm{LE}_{\text {canopy }}$ by substantially increasing $\mathrm{H}_{\text {soil }}$ and $\mathrm{H}_{\text {mulch }}$ directed toward the canopy (Fig. 2). One would expect higher rates of transpiration from seedlings grown on black plastic mulch than from those grown on bare soil because of the potentially large values of $\mathrm{H}_{\text {mulch }}$. In sparse cotton (Ham et al., 1991), wet soil in effect reduced $\mathrm{LE}_{\text {canopy }}$ by cooling the soil surface, thereby reducing the magnitude or changing the direction of $\mathrm{H}_{\text {soil }}$ and simultaneously reducing the amount of $R_{S}$ reflected into the canopy by increasing $\alpha_{\text {sw }}$ (Table 2). A dry soil surface sharply reduced $\mathrm{LE}_{\text {soil }}$ but increased $\mathrm{LE}_{\text {canopy }}$ because of advection. Because of $\mathrm{LE}_{\text {canopy }}$, transpiring vegetation generally is cooler than the surrounding air; therefore, $\mathrm{H}_{\text {canopy }}$ during the day usually is positive as the air warms the plant surface. The opposite (negative $\mathrm{H}_{\text {canopy }}$ ) often occurs at night if the canopy temperature rises above that of the air because $\mathrm{LE}_{\text {canopy }}$ is negligible at night.

\section{CONCLUSION}

Growing most crops on plastic mulch results in partial canopy cover; consequently, the energy balances of both the mulch and the bare soil between rows affect the exchange of energy (i.e., heat) between the plant and its environment. Optical properties of the mulch and the extent of mulch-soil contact determine the effect of the plastic on both the above- and below-ground environment. Below-ground effects are manifested primarily in soil temperatures and the rate of conduction between the mulch and the underlying soil surface. The extent of soil warming depends partly on the degree of contact between plastic and soil. Plastics with high shortwave absorptance or high shortwave transmittance can be expected to raise soil temperatures most dramatically. Above-ground effects are primarily due to the optical properties of the mulch and the fact that plastic prevents evaporation (i.e., $\mathrm{LE}_{\text {mulch }}=0$ ). Convection is the major mode of dissipating energy from the mulch surface. The magnitude of $\mathrm{H}_{\text {mulch }}$ depends largely on $\mathrm{R}_{\mathrm{S}}$ and is not measurably influenced by the water content at the bare soil surface between rows of mulch. Black plastic mulch, the industry standard, can transfer by convection a large amount of heat to seedlings or transplants, potentially inducing high rates of transpiration. However, given well-mixed air, high LE $_{\text {soil }}$ from a wet surface may mitigate some of the effects of large quantities of sensible heat $\left(\mathrm{H}_{\text {mulch }}+\mathrm{H}_{\text {soil }}\right)$ directed toward seedlings. Management of the inter-row, bare soil surface should be considered in relation to the soil's influence on the crop energy balance. One's choice of plastic should be guided by the desired above- and below-ground effects, which are determined by the optical properties of the plastic, by mulch-soil contact, and by the geometry of mulched beds. The most effective combinations can be chosen by augmenting one's understanding of crop biology with an understanding of the physics of a surface energy balance.

\section{Literature Cited}

Adams, J.C. 1997. Mulching improves early growth of four oak species in plantation establishment. Southern J. Appl. For. 21:44-46.

Antonius, G.F., M.J. Kasperbauer, and M.E. Byers. 1996. Light reflected from colored mulches to growing turnip leaves affects glucosinate and sugar contents of edible roots. Photochemphotobiol. 64:605-610.

Arkin, G.F. and E.R. Perrier. 1974. Vorticular air flow within an open row crop canopy. Agr.
Meteorol. 13:359-374.

Avissar, R., Y. Mahrer, L. Margulies, and J. Katan. 1986. Field aging of transparent polyethylene mulches: I. Photometric properties. Soil Sci. Soc. Amer. J. 50:202-205.

Baker, J.M. and C.H.M. Van Bavel. 1987. Measurement of mass flow of water in the stems of herbaceous plants. Plant Cell Environ. 10:777782.

Bhella, H.S. 1988. Tomato response to trickle irrigation and black polyethylene mulch. J. Amer. Soc. Hort. Sci. 113:543-546.

Bhella, H.S. and W.F. Kwolek. 1984. The effects of trickle irrigation and plastic mulch on zucchini. HortScience 19:410-411.

Bonanno, A.R. and W.J. Lamont. 1987. Effect of polyethylene mulches, irrigation method, and row covers on soil and air temperature and yield of muskmelon. J. Amer. Soc. Hort. Sci. 112:735738.

Bremer, D.J., J.M. Ham, and C.E. Owensby. 1996. Effect of elevated atmospheric carbon dioxide and open-top chambers on transpiration in a tallgrass prairie. J. Environ. Qual. 25:691-701.

Brenner, A.J. and P.G. Jarvis. 1995. A heated leaf replica technique for determination of leaf boundary layer conductance in the field. Agr. For. Meteorol. 72:261-275.

Brown, J.E., J.M. Dangler, F.M. Woods, K.M. Tilt, M.D. Henshaw, W.A. Griffey, and M.S. West. 1993. Delay in mosaic virus onset and aphid vector reduction in summer squash grown on reflective mulches. HortScience 28:895-896.

Brown, K.W. and W. Covey. 1966. The energybudget evaluation of the micrometeorological transfer processes within a cornfield. Agr. Meteorol. 3:73-96.

Brunel, J.P. 1989. Estimation of sensible heat flux from measurements of surface radiative temperature and air temperature at two meters: applications to determine actual evaporation rate. Agr. For. Meteorol. 46:179-191.

Brutsaert, W. 1982. Evaporation into the atmosphere. D. Reidel, Boston.

Buettner, K.J.K. and C.D. Kern. 1965. The determination of infrared emissivities of terrestrial surfaces. J. Geophys. Res. 70:1329-1337.

Campbell, G.S., C. Calissendorff, and J.H. Williams. 1991. Probe for measuring soil specific heat using a heat-pulse method. Soil Sci. Soc. Amer. J. 55:291-293.

Campbell, G.S. and J.M. Norman. 1998. An introduction to environmental biophysics. Springer, New York.

Cavero, J., R.G. Ortega, and C. Zaragoza. 1996. Clear plastic mulch improves seedling emergence of direct-seeded pepper. HortScience 31:70-73.

Cebula, S. 1995. Black and transparent plastic mulches in greenhouse production of sweet pepper. II. Light conditions and the generative development of plants. Folia Hort. 7:59-67.

Chellami, D.O., S.M. Olson, D.J. Mitchell, I. Secker, and R. McSorley. 1997. Adaptations of soil solarization to the integrated management of soilborne pests of tomatoes under humid conditions. Phytopathology 87:250-258.

Chen, J.M., Y.B. Yang, and R.H. Zhang. 1989. Soil thermal emissivity as affected by its water content and surface treatment. Soil Sci. 148:433435.

Chin Choy, E.W. and E.T. Kanemasu. 1974. Energy balance comparisons of wide and narrow row spacings in sorghum. Agron. J. 66:98-100.

Csizinsky, A.A., D.J. Schuster, and J.B. King. 1995. Color mulches influence yield and pest populations in tomatoes. J. Amer. Soc. Hort. Sci. 120:778-784.

Davies, J.A. and P.H. Buttimor. 1969. Reflection 
coefficients, heating coefficients, and net radiation at Simcoe, southern Ontario. Agr. Meteorol. 6:373-386.

Davies, J.A. and S.B. Idso. 1979. Estimating the surface radiation balance and its components, $\mathrm{p}$. 183-210. In: B.J. Barfield and J.F. Gerber (eds.). Modification of the aerial environment of plants. ASAE Monogr. 2, Amer. Soc. Agr. Eng., St. Joseph, Mich.

Davis, J.M. 1994. Comparison of mulches for freshmarket basil production. HortScience 29:267268.

Decoteau, D.R., M.J. Kasperbauer, D.D. Daniels, and P.G. Hunt. 1988. Plastic mulch color effects on reflected light and tomato plant growth. Scientia Hort. 34:169-175.

Decoteau, D.R., M.J. Kasperbauer, and P.G. Hunt. 1989. Mulch surface color affects yield of freshmarket tomatoes. J. Amer. Soc. Hort. Sci. 114:216-219.

Decoteau, D.R. and B.B. Rhodes. 1990. Characteristics and effectiveness of photodegradable mulch for use in watermelon production. Appl. Agr. Res. 5:9-12.

Dugas, W.A. 1990. Comparative measurement of stem flow and transpiration in cotton. Theor. Appl. Climatol. 42:215-221.

Fisher, P.D. 1995. An alternative plastic mulching system for improved water management in dryland maize production. Agr. Water Mgt. 27:155166.

Fritschen, L.J. 1967. Net and solar radiation relations over irrigated field crops. Agr. Meteorol. 4:55-62

Fuchs, M. 1986. Heat flux, p. 957-968. In: A. Klute (ed.). Methods of soil analysis: Physical and mineralogical methods. Agron. Monogr. no. 9 (Part 1). Amer. Soc. Agron., Soil Sci. Soc. Amer., Madison, Wis.

Fuchs, M. and C.B. Tanner. 1966. Infrared thermometry of vegetation. Agron. J. 58:597-601.

Gates, D.M. 1980. Biophysical ecology. SpringerVerlag. New York.

Gavloski, J.E., G.H. Whitfield, and C.R. Ellis. 1992. Effect of restricted watering on sap flow and growth in corn (Zea mays L.). Can. J. Plant Sci. 72:361-368.

Graham, H.A.H., D.R. Decoteau, and D.E. Linville. 1995. Development of a polyethylene mulch system that changes color in the field. HortScience 30:265-269.

Graser, E.A. and C.H.M. Van Bavel. 1982. The effect of soil moisture upon soil albedo. Agr. Meterol. 27:17-26.

Green, S.R. 1993. Radiation balance, transpiration and photosynthesis of an isolated tree. Agr. For. Meteorol. 64:210-221.

Green, S.R., K.G. McNaughton, D.H. Greer, and D.J. McLeod. 1995. Measurement of increased $P A R$ and net all-wave radiation absorption by an apple tree caused by applying a reflective ground covering. Agr. For. Meteorol. 76:163-183.

Grinstein, A., G. Kritzman, A. Hetzroni, A. Gamleil, M. Mor, and J. Katan. 1995. The border effect of soil solarization. Crop Protection 14:315-320.

Groot, A. and K.M. King. 1992. Measurement of sap flow by heat balance method: numerical analysis and application to coniferous seedlings. Agr. For. Meteorol. 59:289-308.

Gupta, R. and C.L. Acharya. 1993. Effect of mulchinduced hydrothermal regime on root growth, water use efficiency, yield, and quality of strawberry. J. Indian Soc. Soil Sci. 41:17-25.

Gurnah, A.M. and J. Mutea. 1982. Effects of mulches on soil temperatures under Arabica coffee at Kabete, Kenya Agr. Meteorol. 25:237-244.

Gutiérrez, M.V. and F.C. Meinzer, 1994. Energy balance and latent heat flux partitioning in cof- fee hedgerows at different stages of canopy development. Agr. For. Meteorol. 68:173-186. Ham, J.M., Heilman, J.L., and Lascano, R.J. 1990. Determination of soil water evaporation and transpiration from energy balance and stem flow measurements. Agr. For. Meteorol. 52:287-301.

Ham, J.M., Heilman, J.L., and Lascano, R.J. 1991. Soil and canopy energy balances of a row crop at partial cover. Agron. J. 83:744-753.

Ham, J.M. and G.J. Kluitenberg. 1994. Modeling the effect of mulch optical properties and mulchsoil contact resistance on soil heating under plastic mulch culture. Agr. For. Meteorol. 71:403-424.

Ham, J.M., G.J. Kluitenberg, and W.J. Lamont. 1993. Optical properties of plastic mulches affect the field temperature regime. J. Amer. Soc. Hort. Sci. 118:188-193.

Ham, J.M. and R.S. Senock. 1992. On the measurement of soil surface temperature. Soil Sci. Soc. Amer. J. 56:370-377.

Hanks, R.J., L.H. Allen, and H.R. Gardner. 1971. Advection and evapotranspiration of wide-row sorghum in the central Great Plains. Agron. J. 63:520-527.

Hanna, H.Y., E.P. Millhollon, J.K. Herrick, and C.L. Fletcher. 1997. Increased yield of heattolerant tomatoes with deep transplanting, morning irrigation, and white mulch. HortScience 32:224-226.

Heilman, J.L., W.E. Heilman, and D.G. Moore 1981. Remote sensing of canopy temperature at incomplete cover. Agron. J. 73:403-406.

Heilman, J.L., K.J. McInnes, M.J. Savage, R.W. Gesch, and R.J. Lascano. 1994. Soil and canopy energy balances in a west Texas vineyard. Agr. For. Meteorol. 71:99-114.

Heilman, J.L., K.J. McInnes, R.W. Gesch, R.J. Lascano, and M.J. Savage. 1996. Effects of trellising on the energy balance of a vineyard. Agr. For. Meteorol. 81:79-93.

Hochmuth, G.J. and J.C. Howell. 1983. Effect of black plastic mulch and raised beds on sweet potato growth and root yield in a northern region. HortScience 18:467-468.

Houle, G. and P. Babeux. 1994. Fertilizing and mulching influence on the performance of four native woody species suitable for revegetation in subarctic Quebec. Can. J. For. Res. 24:23422349.

Huband, N.D.S. and J.L. Monteith. 1986. Radiative surface temperature and energy balance of a wheat canopy. I. Comparison of radiative and aerodynamic canopy temperature. BoundaryLayer Meteorol. 36:1-17.

Idso, S.B. 1974. The calibration and use of net radiometers, p. 261-275. In: N.C. Brady (ed.). Adv. Agron. 26:261-275. Academic Press, New York.

Idso, S.B., D.G. Baker, and D.M. Gates. 1966. The energy environment of plants, p. 171-218. In: A.G. Norman (ed.). Adv. Agronomy 18:171218. Academic Press, New York.

Idso, S.B., R.D. Jackson, W.L. Ehrler, and S.T. Mitchell. 1969. A method for determination of infrared emittance of leaves. Ecology 50:899902.

Idso, S.B., R.D. Jackson, R.J. Reginato, B.A Kimball, and F.S. Nakayama. 1975. The dependence of bare soil albedo on soil water content. J. Appl. Meteorol. 14:109-113.

Jacobs, A.F.G. and W.A.J. Van Pul. 1990. Seasonal changes in the albedo of a maize crop during two seasons. Agr. For. Meteorol. 49:351-360.

Jones, F.E. 1992. Evaporation of water. Lewis Pub1., Chelsea, Mich.

Kasperbauer, M.J. and R.E. Wilkinson, 1995. Mulch surface color affects accumulation of epicuticu- lar wax on developing leaves. Photochemphotobiol. 62:940-944.

Kimball, B.A. and R.D. Jackson. 1979. Soil heat flux, p. 211-229. In: B.J. Barfield and J.F. Gerber (eds.). Modifications of the aerial environment of plants. Monogr. No. 2. Amer. Soc. Agr. Eng., St. Joseph, Mich.

Kustas, W.P. 1990. Estimates of evapotranspiration with a one- and two-layer model of heat transfer over partial canopy cover. J. Appl. Meteorol. 29:704-715.

Larcher, W. 1980. Physiological plant ecology. Springer-Verlag, New York.

Lhomme, J.-P. 1991. The concept of canopy resistance: historical survey and comparison of different approaches. Agr. For. Meteorol. 54:227240.

Lhomme, J.-P., B. Monteny, and M. Amadou. 1994. Estimating sensible heat flux from radiometric temperature over sparse millet. Agr. For. Meteorol. 68:77-91.

Liakatas, A., J.A. Clark, and J.L. Monteith. 1986. Measurements of the heat balance under plastic mulches. Agr. For. Meteorol. 36:227-239.

Mahrer, Y. and J. Katan. 1981. Spatial soil temperature regime under transparent polyethylene mulch: numerical and experimental studies. Soil Sci. 131:82-87.

Mashingaidze, A.B., O.A. Chivinge, and C. Zishiri. 1996. The effects of clear and black plastic mulch on soil temperature, weed seed viability and seedling emergence, growth and yield of tomatoes. J. Appl. Sci. South. Africa 2:6-14.

Mayocchi, C.L. and K.L. Bristow. 1995. Soil surface heat flux: some general questions and comments on measurements. Agr. For. Meteorol. 75:43-50.

McInnes, K.J., J.L. Heilman, and M.J. Savage. 1994. Aerodynamic conductances along a bare ridefurrow tilled soil surface. Agr. For. Meteorol. 68:119-131.

McInnes, K.J., J.L. Heilman, and R.J. Lascano. 1996. Aerodynamic conductances at the soil surface in a vineyard. Agr. For. Meteorol. 79:2937.

McNaughton, K.G., S.R. Green, T.A. Black, B.R. Tynan, and W.R.N. Edwards. 1992. Direct measurement of net radiation and photosynthetically active radiation absorbed by a single tree. Agr. For. Meteorol. 62:87-107.

Monteith, J.L. 1959. The reflection of shortwave radiation by vegetation. Quart. J. Royal Meteorol. Soc. 85:386-392.

Monteith, J.L. 1965. Evaporation and environment, p. 205-234. In: G.E. Fogg (ed.). The state and movement of water in living organisms. Symp. Soc. Expt. Biol. Academic Press, New York.

Monteith, J.L. and J.F. Elston. 1971. Microclimatology and crop production. p. 23-42. In: P.F. Wareing and J.P. Cooper (eds.). Potential crop production: A case study. Heinemann, London.

Monteith, J.L. and M.H. Unsworth. 1990. Principles of environmental physics. 2nd ed. Edward Arnold, London.

Moss, R.A. and W.E. Loomis. 1952. Absorption spectra of leaves. 1. The visible spectrum. Plant Physiol. 27:370-391.

Nkemdirin, L.C. 1973. Radiative flux relations over crops. Agr. Meteorol. 11:229-242.

Nobel, P.S. 1974. Biophysical plant physiology. W.H. Freeman, San Francisco.

Perrier, E.R., R.J. Millington, D.B. Peters, and R.J. Luxmoore. 1970. Wind structure above and within a soybean canopy. Agron. J. 62:615-618.

Perrier, E.R., J.M. Robinson, R.J. Millington, and D.B. Peters. 1972. Spatial and temporal variation of wind above and within a soybean canopy. Agr. Meteorol. 10:421-442. 
Ricotta, J.A. and J.B. Masiunas. 1991. The effects of black plastic mulch and weed control strategies on herb yield. HortScience. 26:539-541.

Richardson, A., P. Mooney, T. Dawson, P. Anderson, W.J. Killen, and M. Astill. 1993. Satsuma mandarin quality is improved using a reflective mulch. Orchardist N.Z. 66:36-38.

Roberts, B.W. and J.A. Anderson. 1994. Canopy shade and soil mulch affect yield and solar injury in pepper. HortScience 29:258-260.

Sakuratani, T. 1981. A heat balance method for measuring water flux in the stem of intact plants. J. Agr. Meteorol. 37:9-17.

Sakuratani, T. 1984. Improvement of the probe for measuring water flow rate in intact plants with the heat balance method. J. Agr. Meteorol. 40:273-277.

Schales, F.D. 1990. Agricultural plastics use in the United States. Proc. 11th Intl. Congr. Plast. Agr. J.54-J.56.

Soltani, N., J.L. Anderson, and A.R. Hamson. 1995. Growth analysis of watermelon plants grown with mulches and rowcovers. J. Amer. Soc. Hort. Sci. 120:1001-1009.

Sowers, R.S. and M.S. Welterlen. 1988. Seasonal establishment of bermudagrass using plastic and straw mulches. Agron. J. 80:144-148.

Splittstoesser, W.E. and J.E. Brown. 1991. Current changes in plasticulture for crop production. Proc. Natl. Agr. Plast. Congr. 23:241-253.

Steinberg, S.L., M.J. McFarland, and J.W. Worthington. 1990. Comparison of trunk and branch sap flow with canopy transpiration in pecan. J. Expt. Bot. 41:653-659.

Stevens, C., V.A. Khan, J.E. Brown, G.J. Hochmuth,
W.E. Splittstoesser, and D.M. Granberry. 1991. Plastic chemistry and technology as related to plasticulture and solar heating of the soil, p. 141158. In: J. Katan and J.E. Devey (eds.). Soil solarization. CRC Press, Boca Raton, Fla.

Stewart, J.B., W.P. Kustas, K.S. Humes, W.D. Nichols, M.S. Moran, and H.A.R. de Bruin. 1994. Sensible heat flux-Radiometric surface temperature relationship in eight semiarid areas. J. Appl. Meteorol. 33:1110-1115.

Tanner, C.B. 1960. Energy balance approach to evapotranspiration from crops. Soil Sci. Soc. Amer. Proc. 24:1-9.

Tanner, C.B. 1974. Microclimate modification: Basic concepts. HortScience 9:555-560.

Tarara, J.M. and J.M. Ham. 1997. Measuring soil water content in the laboratory and field with dual-probe heat-capacity sensors. Agron. J. 89:535-542.

Tarara, J.M. and J.M. Ham. 1999. Measuring sensible heat transport in plastic mulch culture with aerodynamic conductance sensors. Agr. For. Meteorol. 95:1-13.

Teasdale, J.R. and A.A. Abdul-Baki. 1995. Soil temperature and tomato growth associated with black polyethylene and hairy vetch mulches. J. Amer. Soc. Hort. Sci. 120:848-853.

Teasdale, J.R. and A.A. Abdul-Baki. 1997. Growth analysis of tomatoes in black polyethylene and hairy vetch production systems. HortScience 32:659-663.

Van den Honert, T.H. 1948. Water transport in plants as a catenary process. Disc. Faraday Soc. 3:146-153.

Van der Werf, H.G.M. 1993. The effect of plastic mulch and greenhouse raised seedlings on yield of maize. J. Agron. Crop Sci. 170:261-269.

VanDerwerken, J.E. and D. Wilcox-Lee. 1988. Influence of plastic mulch and type and frequency of irrigation on growth and yield of bell pepper. HortScience 23:985-988.

Vos, J.G.M. and N. Sumarni. 1997. Integrated crop management of hot pepper (Capsicum spp.) under tropical lowland conditions: effects of mulch on crop performance and production. J. Hort. Sci. 72:415-424.

Vos, J.G.M. T.S. Uhan, and R. Sutarya. 1995. Integrated crop management of hot pepper (Capsicum spp.) under tropical lowland conditions: effects of rice straw and plastic mulches on crop health. Crop Protection 14:445-452.

Waggoner, P.E., P.M. Miller, and H.C. De Roo, 1960. Plastic mulching: Principles and benefits. Connecticut Agric. Expt. Stat. Bul. 634.

Wien, H.C. and P.L. Minotti. 1987. Growth, yield and nutrient uptake of transplanted fresh-market tomatoes as affected by plastic mulch and initial nitrogen rate. J. Amer. Soc. Hort. Sci. 112:759763.

Wien, H.C. and P.L. Minotti. 1988. Increasing yield of tomatoes with plastic mulch and apex removal. J. Amer. Soc. Hort. Sci. 113:342-347.

Wien, H.C., P.L. Minotti, and V.P. Grubinger. 1993. Polyethylene mulch stimulates early root growth and nutrient uptake of transplanted tomatoes. J. Amer. Soc. Hort. Sci. 118:207-211.

Wu, Y., K.B. Perry, and J.B. Ristaino. 1996. Estimating temperature of mulched and bare soil from meteorological data. Agr. For. Meteorol. 81:299-323. 